\title{
ANALISIS SISTEM REKRUTMEN TERHADAP KINERJA KARYAWAN OUTSOURCING
}

\author{
*(Nurul Badriyah \\ Fakultas Ekonomi \\ Universitas Islam Lamonagan
}

\begin{abstract}
ABSTRAK
Untuk menghadapi persaingan bisnis di era-globalisasi yang semakin pesat, sebuah perusahaan harus memiliki sumber daya manusia/karyawan sebagai tenaga kerja yang memiliki kualitas tinggi. Mengingat karyawan merupakan aset penting sebuah perusahaan, oleh karena itu banyak hal yang perlu diperhatikan dalam peningkatan kinerjanya. Kinerja yang baik merupakan salah satu sasaran perusahaan dalam mencapai produktifitas kerja yang tinggi. Tercapainya kinerja perusahaan yang baik tidak lepas dari sumber daya manusia yang baik juga. Oleh karena itu untuk dapat mewujudkannya maka karyawan harus memiliki keahlian dan keterampilan sesuai dengan perkerjaanya. Masalah yang hendak dicari jawabannya dalam penelitian ini adalah pengaruh sistem rekrutmen terhadap kinerja karyawan outsourcing PT. Alumad Artha Prima (AAP). Sejalan dengan permasalah tersebut, diajukan hipotesis diduga sistem rekrutmen berpengaruh teradap kinerja karyawan outsourcing pada PT. Alumad Artha Prima (AAP). Hasil analisis menunjukkan bahwa, hasil uji validitas lebih dari $r_{\text {tabel }}$ 0,349 dan hasi uji reliabilitas $(0,870)$ menunjukkan hasil valid dan reliabel. Berdasarkan uji hipotesis terhadap sistem rekrutmen terhadap kinerja karyawan outsourcing PT. Alumada Artha Prima (AAP), dari perhitungan koefisien korelasi hasilnya $(X)=0,656$, sedangkan uji regresi sederhana $Y=9,66+0,26 X$ dari uji $t$ sebesar $t_{\text {hitung }} X$ $4,596>t_{\text {tabel }} 2,048$, maka dapat diartikan bahwa adanya sistem rekrutmen berpengaruh secara signifikan terhadap kinerja karyawan outsourcing terbukti. Dari bukti tersebut dapat disimpulkan bahwa sistem rekrutmen memiliki pengaruh yang signifikan terhadap kinerja karyawan outsourcing. Saran - Saran : hendaknya untuk senantiasa melengkapi fasilitas yang terdapat di PT. Alumada Artha Prima (AAP) dan meningkatkan pelatihan-pelatihan untuk menambah nilai jual PT. Alumada Artha Prima (AAP).
\end{abstract}

Kata Kunci : Sistem Rekrutmen dan Kinerja Karyawan

\section{PENDAHULUAN}

Memasuki dunia bisnis dalam eraglobalisasi yang semakin pesat dengan ditandainya revolusi komunikasi dan teknologi informasi telah mengakibatkan terjadinya perubahan yang luar biasa. Laju pertumbuhan ekonomi yang semakin meningkat di-iringi oleh berkembangnya berbagai macam perusahaan industri dan jasa mengakibatkan meningkatan persaingan. Rekrutmen atau penarikan tenaga kerja merupakan proses mencari, menemukan dan menarik para calon karyawan untuk menjadi karyawan pada perusahaan tersebut. Tujuan dalam proses rekrutmen agar mendapatkan pegawai yang handal sehingga meskipun jumlah karyawan yang dimiliki perusahaan tidak banyak namun tugas dan fungsi dapat ditunaikan dengan lancar. Menurut Sirait, (2006: 57), Rekrutmen atau penarikan calon pegawai merupakan 
serangkaian kegiatan yang dilakukan secara terencana, untuk memperoleh calon-calon karyawan yang memenuhi syarat-syarat yang dituntut oleh suatu jabatan tertentu yang dibutuhkan oleh suatu organisasi.

Untuk menghadapi persaingan tersebut sebuah perusahaan harus memiliki sumber daya manusia/karyawan sebagai tenaga kerja yang memiliki kualitas tinggi. Mengingat karyawan merupakan aset penting sebuah perusahaan, oleh karena itu banyak hal yang perlu diperhatikan dalam peningkatan kinerjanya. Kinerja yang baik merupakan salah satu sasaran perusahaan dalam mencapai produktifitas kerja yang tinggi. Tercapainya kinerja perusahaan yang baik tidak lepas dari sumber daya manusia yang baik juga. Oleh karena itu untuk dapat mewujudkannya maka karyawan harus memiliki keahlian dan keterampilan sesuai dengan perkerjaanya.

Kinerja seorang pegawai yang baik, jika pegawai memiliki keahlian yang tinggi, kesediaan untuk bekerja, adanya imbalan/upah yang layak dan mempunyai harapan masa depan. Kinerja yang optimal akan terwujud bilamana organisasi dapat memilih karyawan yang meliliki motivasi dan kecapakan yang sesuai dengan pekerjaannya serta memiliki kondisi yang memmungkinkan mereka agar dapat berkerja secara maksimal. (Mathis, 2006 : 378).

Karyawan merupakan sumber daya yang paling tinggi dalam sebuah perusahaan. Karyawan yang baik dan memenuhi standar kualifikasi hanya akan diperoleh melalui proses rekrutmen yang efektif. Supaya dapat melakukan proses tersebut harus tersedia informasi yang akurat dan berkelanjutan mengenai jumlah dan kualifikasi individu yang diperlukan untuk melaksanakan tugas pokok dan fungsi dalam sebuah perusahaan.

Hasibuan (2008:41) menyatakan bahwa rekrutmen merupakan usaha mencari dan mempengaruhi tenaga kerja, agar mau melamar lowongan pekerjaan yang ada dalam suatu organisasi. Sedangkan pengertian rekrutmen menurut Simamora (2004:170) merupakan serangkaian aktivitas mencari dan memikat pelamar kerja dengan motivasi, kemampuan, keahlian, dan pengetahuan yang diperlukan untuk menutupi kekurangan yang diidentifikasi dalam perencanaan kepegawaian. Aktivitas rekrutmen dimulai pada saat calon mulai dicari, dan berakhir pada saat lamaran mereka diserahkan.

Maksud dilakukan rekrutmen adalah untuk mendapatkan persediaan sebanyak mungkin calon-calon pegawai sehingga organisasi akan mempunyai kesempatan yang lebih besar untuk melakukan pilihan terhadap calon-calon pegawai yang dianggap memenuhi standar kualifikasi perusahaan. Tujuan dari rekrutmen tidak lain untuk mendapatkan tenaga kerja yang paling tepat untuk memangku jabatan tertentu. Proses rekrutmen dimulai setelah kumpulan para pelamar yang memenuhi persayaratan, yang melalui serangkaian langkah kegiatan untuk memutuskan apakah pelamar diterima atau ditolak.

Menurut Sirait (2006:56), aspek-aspek yang ada dalam system rekrutmen, yaitu:

\section{Proses seleksi}

Prose Seleksi adalah rangkaian kegiatan yang di lakukan oleh perusahaan/organisasi untuk dapat mengambil keputusan tentang siapa-siapa dari calon pegawai yang paling tepat (memenuhi syarat) untuk bisa diterima menjadi pegawai.

\section{Penempatan}

Penempatan adalah suatu pengaturan awal atau pengaturan kembali dari seseorang atau lebih pegawai pada suatu jabatan baru ataupun jabatan yang berlainan. Bagi pegawai baru, penempatan artinya pengaturan awal pada suatu jabatan bagi pegawai yang baru bekerja. 
Penempatan tenaga kerja adalah proses pemberian tugas dan pekerjaan kepada tenaga kerja yang lulus seleksi untuk dilaksanakan sesuai ruang lingkup yang telah ditetapkan serta mmapu mempertanggung jawabkan segala resiko dan kemungkinan-kemungkinan yang terjadi atas tugas dan perkerjaan, wewenang serta tanggung jawab.

\section{Orientasi/sosialisasi}

Orientasi/sosialisasi adalah penyesuaian diri, baik dari aspek psikis, jasmani, psikologi, peranan (hubungan dengan pekerjaan yang dilakukan).

Bagi tenaga kerja baru yang telah memperoleh surat penemapatan tugas, orientasi merupakan proses untuk mengetahui dan mnegenal tempat kerjanya dalam totalitas hubungan pekrejaan. Oleh karena itu orientasi terhadap tenaga kerja baru dalam melaksanakan kegiatan penting dan harus dilaksanakan.

Dalam melakukan fungsi personalia, seyogyanya ada perencanaan tenaga kerja atau perencanaan sumber daya manusia, yaitu langkah-langkah tertentu yang diambil oleh menejemen sebuah perusahaan yang lebih menjamim bahwa bagi perusahaan tersedia tenaga kerja yang tepat untuk menduduki berbagai jabatan. Dari pengertian tersebut intinya yang tercantum dalam suatu perencanaan tenaga kerja adalah menyediakan tenaga kerja yang tepat pada jabatan yang tepat dan waktu yang tepat pula.

Menurut Hasibun (2008 : 94), bahwa kinerja adalah suatu hasil kerja yang dicapai seseorang dalam melaksanakan tugas-tugas yang dibebankan kepadanya yang didasarkan atas kecakapan, pengalaman, kesungguhan serta waktu. Kinerja merupakan perwujudan kerja yang dilakukan oleh pegawai atau organisasi. Kinerja yang dimaksud adalah sesuatu yang dikerjakan atau produk atau jasa yang dihasilkan atau diberikan seseorang atau sekelompok orang. Dari pendapat tersebut dapat disimpulkan bahwa kinerja adalah hasil kerja yang dicapai seseorang baik berupa produk atau jasa dalam pelaksanaan pekerjaannya sesuai beban tugas yang harus dilakukan.

Kinerja atau prestasi kerja (job performance) didefinisikan dalam beragam rumusan. Akantetapi pengertian kinerja pada umumnya menunjukka keberhasilan pegawai dalam menjalankan tugas-tugas pekerjaan menurut kriteria yang ditentukan untuk jangka waktu tertentu. Menurut As'ad (2000 : 47) mendefinisikan prestasi kerja sebagai kesuksesan seseorang dalam melaksankan perkejaan atau "successful role achievement" yang diperoleh seseorang dalam perbuatannya.

Hasil kerja (bahasa Inggris: deliverable) adalah objek berwujud atau tak berwujud yang merupakan hasil pelaksaan proyek, sebagai bagian dari suatu kewajiban atau obligasi. Istilah yang biasa dikaitkan secara spesifik dengan objektif ini, dapat berupa suatu kata benda: suatu barang, produk, atau artefak yang harus dibuat dan diberikan sebagai bagian kewajiban, atau suatu kata keterangan: menjelaskan sesuatu yang harus diberikan sebagai bagian dari kewajiban. (http://id.wikipedia.org/wiki/Hasil_kerja).

\section{a. Perilaku Kerja}

Menurut Robbins (2002 : 35 dan 39 ),Perilaku kerja yaitu dimana orang-orang dalam lingkungan kerja dapat mengaktualisasikan dirinya melalui sikap dalam bekerja. (Robbins menekankan pada sikap yang diambil oleh pekerja untuk menentukan apa yang akan mereka lakukan di lingungan tempat kerja mereka).

\section{b. Sifat Pribadi}

Sifat pribadi yang sering disebut juga dengan kepribadian, adalah keseluruhan cara seorang individu bereaksi dan berinteraksi dengan individu lain. Kepribadian paling sering 
dideskripsikan dalam istilah sifat yang bisa diukur yang ditunjukkan oleh seseorang.

Untuk keperluan mengukur kinerja, pekerjaan dibagi menjadi dua, seperti direkomendasikan Meiyer (dalam As'ad, 2000:52), yaitu (a) pekerjaan produksi yang secara kuantitafif dapat dibuat standart obyektif, dan (b) pekerjaan non produksi, dimana penentuan sukses tidaknya seseorang didalam menjalankan tugas didapat melalui human judgement atau pertimbangan subyektif. Kesimpulannya adalah pengukuran kinerja berbeda-beda tergantung dari jenis pekerjaan dan tujuan-tujuan yang ingin dicapai perusahaan.

Persaingan dalam dunia bisnis antara perusahaan, membuat perusahaan harus berkonsentrasi pada rangkaian proses atau aktivitas penciptaan produk dan jasa yang terkait dengan kompetensi utamanya. Dengan adanya konsentrasi terhadap kompetensi utama dari perusahaan, akan dihasilkan sejumlah produk dan jasa memiliki kualitas yang memiliki daya saing di pasaran. Dalam iklim perusahaan yang makin ketat, perusahaan berusaha untuk melakukan efesiensi biaya produksi (cost of production). Salah satu solusinya adalah dengan sistem outsourcing, dimana dengan sistem ini perusahaan dapat menghemat pengeluaran dalam membiayai sumber daya manusia yang bekerja di perusahaan bersangkutan.

Outsourcing (Alih Daya) diartikan sebagai pemindahan atau pendelegasian beberapa proses bisnis kepada suatu badan penyedia jasa, dimana badan penyedia jasa tersebut melakukan proses administrasi dan manajemen berdasarkan definisi serta kriteria yang telah disepakati oleh para pihak (Sjahputra, 2009:308).

Dalam Inpres No. 3 Tahun 2006 tentang paket kebijakan Iklim Investasi disebutkan bahwa outsourcing (Alih Daya) sebagai salah satu faktor yang harus diperhatikan dengan serius dalam menarik iklim investasi ke Indonesia. Bentuk keseriusan pemerintahan tersebut dengan menugaskan menteri tenaga kerja untuk membuat draft revisi terhadap Undang-Undang Nomor 13 Tahun 2003 Tentang Ketenagakerjaan.

\section{METODELOGI PENELITIAN}

Penelitian ini pendekatan yang dilakukan yakni dengan menggunakan metode penelitian deskriptif kuantitatif yang dilakukan selama \pm 6 bulan (Januari - Juni 2014), dan memilih lokasi sebagai bahan penelitian pada PT. Alumada Artha Prima (AAP) yang beralamat di Taman Suko Asri Blok F no. 33 RT 30 RW 08 Sukodono -Sidoarjo. Dalam penelitian ini populasi yang diguankan adalah karyawan outsourcing PT. Alumada Artha Prima (AAP) selama januari 2013 - desember 2013 yang berjumlah 130 orang dan sampel yang digunakan dalam penelitian ini adalah sistem rekrutmen yaitu karyawan yang melalui proses rekrutmen di PT. Alumada Artha Prima berjumlah 30 orang dengan mengguankan skala Likert yaitu digunakan untuk mengukur sikap, pendapatan, dan persepsi seeorang atau sekelompok yang tentang fenomena social (Sugiyono, $2008: 93$ ).

Dalam penelitian ini jenis kelamin res6yt5ponden keseluruhan adalah laki-laki dengan persentase $100 \%$ sebanyak 30 orang. Dan latar belakang responden terbanyak adalah SMA dengan jumlah 29 orang atau dalam persentase $97 \%$, sedangkan responden yang berpendidikan D 3 sebanyak 1 orang atau 3\% dengan usia termuda responden adalah 20 tahun dengan persentase sebesar $13 \%$ sebanyak 4 orang, usia 21 predengan presentasi 3\% sebanyak 1 orang, usia 22 dengan presentase $7 \%$ sebanyak 2 orang, usia 23 denagn presentase $3 \%$ sebanyak 1 orang, usia 24 dengan presentase $7 \%$ sebanyak 2 orang, usia 25 dengan presentase $7 \%$ sebanyak 2 orang, usia 26 dengan presentase $7 \%$ sebanyak 2 orang, usia 27 dengan presentase $3 \%$ sebanyak 1 orang, usia 28 dengan presentase $13 \%$ 
sebanyak 4 orang, usia 29 dengan presentase $7 \%$ sebanyak 2 orang, usia 30 dengan presentase $13 \%$ sebanyak 4 orang, usia 32 dengan presentase $10 \%$ sebanyak 3 orang, usia 35 dengan presentase $3 \%$ sebanyak 1 orang, usia 36 denagn presentase $3 \%$ sebanyak 1 orang.

Pada variable system rekrutmen bahwa para responden menilai item pertanyaan yang tentang system rekrutmen adalah baik, seperti contoh pada kesesuaian dengan job derscription, dengan mencantumkan pada media massa, adanya tes untuk para rekrutmen dan juga kebijakan penempatan kerja karyawan yang sesuai dengan hasil seleksi. Dan yang lebih lagi adalah proses rekrutmen dilanjutkan pada proses magang selama periode waktu tertentu yang ditetapkan perusahaaan penyedia jasa.

Pada variable kinerja karyawan didapat bahwa kualitas hasil pekerjaan akan didapat hasil yang baik karena ditunjang dengan factor pengetahuan dan keterampilan karyawan yang telah didapatkan pada waktu rekrutmen, dan juga ada factor kerjasama sesame karyawan untuk mencapai hasil yang diharapkan. Ditunjang juga dengan tanggungjawab tinggi dalam penyelesaian pekerjaaan.

Pada dasarnya analisis data adalah kegiatan untuk merumuskan data sehingga dapat diperoleh suatu kebenaran atau ketidak benaran dari suatau hipotesa. Dalam analisis diperluakan imajinasi dan kreaktifiats sehingga di uji kemampuan peneliti menalar sesuatu. Analisis data di dalam penelitian ini dilakukan melalui beberapa tahap, yaitu : Uji Validitas dan Uji Reliabilitas, Regresi Linier Sederhana, Keoefisien Korelasi, dan Uji t (Uji Parsial)

Menurut Singarimbun (2006:122) validitas merupakan alat ukur yang menunjukkan tingkat kevalidan atau kesahihan suatu instrument. Dikatakan valid jika mampu mengukur peneliti serta dapat mengungkapkan hasil uji validitas dari variabel yang diteliti secara tepat. Uji validitas ini secara manual dihitung dengan cara mengkorelasikan setiap skor item dengan total skor item variabel, kemudian hasilnya dibandingkan $r$ product moment pada tingkat signifikan $95 \%(\alpha=0,05)$, jika $\mathrm{r}$ dihitung $>\mathrm{r}$ product moment lebih besar dari nilai kritis 0,195 maka alat ukur tersebut dinyatakan valid.

Reliabilitas adalah alat yang digunakan untuk mengukur suatu kuesioner yang merupakan indikator dari suatu variabel. Menurut Ferdinand (2011) sebuah instrumen dan data yang dihasilkan disebut reliable atau terpercaya apabila instrumen tersebut secara konsisten memunculkan hasil yang sama setiap kali dilakukan pengukuran. Adapun cara yang digunakan untuk menguji reliabiltas kuesioner dalam penelitian ini adalah menggunakan rumus koefisien Alpha Cronbach.

Menurut Prof. H. Buchori Alma (2007:96), Regresi sederhana dapat dianalisis karena didasari oleh hubungan fungsioanal atau hubungan sebab akibat (kasual) variable bebas (X) terhadpa variabel terikat (Y).

Menurut Prof. Dr, Sudjono, MA (2003:244) koefisien korelasi digunakan untuk mengetahaui hubungan antara system rekrutmen terhadap kinerja karyawan outsourcing, mempunyai hubungan kuat atau tidak.

Untuk uji t (uji parsial) digunakan untuk menguji pengaruh variabel Independent terhadap variabel dependent secara signifikaan dan parsial. (Prof. DR. Sugiyono 2013 : 230)

\section{PEMBAHASAN}

Untuk membuktikan adanya pengaruh antara sistem rekrutmen (X) terhadap kinerja karyawan outsourcing (Y) pada PT. Alumada Artha Prima (AAP) dapat dibuktikan dengan hasil uji sebagai berikut : 
1 Uji Regresi Linier Sederhana dapat diperoleh hasil $\mathrm{Y}=9,66+0,26 \mathrm{X}$

$$
\begin{array}{r}
\text { a =9,66, artinya nilai konstanta yang } \\
\text { menunjukkan nilai kinerja } \\
\text { karyawan sebesar } 9,66 \\
\text { dengan asumsi rekrutmen } \\
\text { karyawan dianggap konstant } \\
(\mathrm{X}=0) \text {. } \\
\mathrm{b}=0,26 \text {, artinya koefisien regresi } \\
\text { yang menyatakan apabila } \\
\text { sistem rekrutmen } \\
\text { dinaikkan } 1 \text { unit maka } \\
\text { kinerja karyawan akan } \\
\text { naik atau bertambah } \\
\text { sebesar } 0,26 \text { dengan } \\
\text { asumsi variabel lain yang } \\
\text { dipengaruhi dianggap } \\
\text { konstant }(\mathrm{a}=0) \text {. }
\end{array}
$$

2. Uji Korelasi diatas dapat dilihat dengan hasil $\mathrm{r}=0,656$ tingkat hubungan kuat antara variable terikat/Y (kinerja karyawa oustsourcing) dengan variabel bebas/X (sister rekrutmen).

3. Uji t, uji hipotesis secara parsial dimana diperoleh hasil Thitung > Ttabel (4,596 > 2,048 ) dengan $\alpha=0,05$ dengan $\mathrm{df}=28$ dan $\mathrm{T}$ tabel $(0,025 ; 28)$. Ho ditolak dan $\mathrm{Hi}$ diterima yang berarti sistem rekrutmen (X) berpengaruh secara signifikan terhadap kinerja karyawan outsourcing (Y). Hipotesa yang menyatakan adanya sisterm rekrutmen karyawan berpengaruh secara signifikan terhadap kinerja karyawan outsourcing terbukti.

\section{KESIMPULAN DAN SARAN}

\section{KESIMPULAN}

Berdasarkan pembahsan diatas maka penulis akan memberikan kesimpulan sebagai berikut :
1. Bedasarkan hasil perhitungan regresi linier sederhana mmepunyai nilai koefisien sebesar $\mathrm{Y}=9,66+0,26 \mathrm{X}$ dengan $a=9,66$, artinya nilai konstanta yang menunjukkan nilai kinerja karyawan sebesar 9,66 dengan asumsi rekrutmen karyawan dianggap konstant $(X=0)$. Dengan $b=0,26$, artinya koefisien regresi yang menyatakan apabila sistem rekrutmen dinaikkan 1 unit maka kinerja karyawan akan naik atau bertambah sebesar 0,26 dengan asumsi variabel lain yang dipengaruhi dianggap konstant $(\mathrm{a}=0)$.

2. Berdasarkan perhitunagan diatas uji korelasi dengan hasil $r=0,656$ tingkat hubungan kuat antara variable terikat/Y (kinerja karyawan oustsourcing) dengan variabel bebas/X (sister rekrutmen).

3. Berdssarkan hasil uji t, uji hipotesis secara parsial dimana diperoleh hasil Thitung>Ttabel $(4,596>2,048)$ dengan $\alpha=0,05$ dengan $\mathrm{df}=28$ dan Ttabel $(0,025 ; 28)$. Ho ditolak dan Hi diterima yang berarti sistem rekrutmen (X) berpengaruh secara signifikan terhadap kinerja karyawan outsourcing (Y). Hipotesa yang menyatakan adanya sisterm rekrutmen karyawan berpengaruh secara signifikan terhadap kinerja karyawan outsourcing terbukti.

\section{SARAN}

Berdasarkan hasil penelitian dan pembahasan maka saran yang dapat diajukan oleh penulis sebagai berikut :

1. Bagi pemilik PT. Alumada Artha Prima (AAP) hendaknya untuk senantiasa melengkapi fasilitas yang terdapat di PT. Alumada Artha Prima (AAP) den meningkatkan pelatihan-pelatihan untuk 
menambah nilai jual PT. Alumada Artha Prima (AAP).

2. Bagi karyawan PT. Alumada Ardha Prima (AAP) hendaknya berusaha untuk senantiasa meningkatkan kualitas kerja.

3. Bagi peneliti selanjutnya, hendaknya memperluas obyek penelitian tidak hanya pada variabel sistem rekrutmen saja tetapi juga pada variabel-variabel lain sehingga diperoleh informasi yang lebih lengkap tentang faktor-faktor yang berpengaruh terhadap kinerja karyawan outsourching PT. Alumada Artha Prima (AAP).

\section{DAFTAR PUSTAKA}

Malthis L Robert and Jakson John 2006.Human Resource Management.Edisi ke sepuluh salemba 4.

Samsudin, H. Sadeli 2010.Manajemen Sumber Daya Manusia. Penerbit : Pustaka Setia, Bandung.

Hasibuan, Melayu, SP 2008.Manajemen Sumber Daya Manusia. Edisi revisi cetakan ketujuh. Penerbit : Bumi Aksara, Jakarta.

Sirait T. Justine 2006.Memahami Aspek-aspek Pengelolahan Sumber Daya Manusia dalam Organisasi. Penerbit : PT.Grasindo, Jakarta.

Moekijat 2010.Manajemen Sumber Daya Manusia. Cetakan ke sembilan. Penerbit : Mandar Maju, Bandung.

Sugiono 2008.Metode Penelitian Kuantitatif, Kualitatif, dan $R \& D$. Cetakan ke lima. Penerbit : Alfabeta, Bandung.

Sekaran, Umah 2006. Metode Penelitian untuk Bisnis. Edisi ke empat. Penerjemah Wan Menyong Salemba 4, Jakarta.
Prof. Dr. H. Buchori Alma 2007.Pengantar Statistika untuk Penelitian Pendidikan, Sosial, Komunikasi, Ekonomi dan Bisnis. Penerbit : Alfabeta, Bandung.

Simamora, Henry 2004.Manajemen Sumber Daya Manusia. Edisi ke tiga. Penerbit : YKPN, Yogyakarta.

Sofyadi Herman 2008. Manajemen Sumber Daya Manusia. Edisi pertama. Penerbit : Graha Ilmu, Jakarta.

Rivai, Vetizal 2009.Manajemen Sumber Daya Manusia untuk Perusahaan. Edisi ke dua. Penerbit : Rajawali Pers. Jakarta.

Rachmawati, Ike Kusdiyah 2008.Manajemen Sumber Daya Manusia. Edisi pertama. Penerbit : Ardi Offset, Jakarta.

Handoko T. Yani 2008.Manajemen Personalia dan Sumber Daya Manusia. Edisi ke dua, Penerbit : BPFE, Yogyakarta. 